\title{
ANALYSIS OF THE EFFECT OF GOVERNMENT ROLE AND SOCIAL CAPITAL IN DISASTER MANAGEMENT ON ECONOMIC RECOVERY OF DISASTER VICTIMS IN THE SARBAGITA AREA OF BALI PROVINCE
}

\author{
Usadhi Putu Agus Wiguna*, Sudibia I Ketut \\ Faculty of Economics and Business, University of Udayana, Bali, Indonesia \\ *E-mail: usadhi@gmail.com
}

\begin{abstract}
Disaster management as part of development requires the common perception of various actors and the integration of its implementation to get results that are right on target, effective, efficient and sustainable, especially in efforts to accelerate the economic recovery of disaster victims. This research was conducted in the Denpasar, Badung and Gianyar regions of Bali Province to analyze the influence of the role of government, social capital and disaster management in the economic recovery of disaster victims. The results of the study show that the role of government and social capital has a positive and significant effect on disaster management. The role of government and social capital in disaster management has a significant effect on economic recovery. The government needs to conduct a more comprehensive study in determining strategies and policies in the field of disaster management and increasing mutual trust between communities and the government. The construction of an early warning system and physical infrastructure need to more concern because the success of the economic recovery program is inseparable from disaster risk reduction efforts.
\end{abstract}

\section{KEY WORDS}

Role of government, social capital, disaster management, economic recovery.

Disaster is a combination of natural and human activities that can cause loss of life, loss of property and damage to the environment and cause the results of development to be damaged or destroyed which can have an impact on the economic collapse of the community both directly and indirectly. In an effort to overcome the impact of the disaster, the Government of Indonesia has enacted Law Number 24 of 2007 concerning Disaster Management which regulates the processes and roles of various parties in the implementation of Disaster Management. There are three pillars of Disaster Management actors, such as the government, the community, and business institutions. Therefore, the implementation of disaster management is not only the government responsibility, but also the community and business institutions. The community and business institutions are required to play an active role in every stage of disaster management from pre-disaster, during emergency response and post-disaster.

It is because the community as the subject of disaster management is the main source of disaster management. Putnam (2002) states that the idea of the core of social capital theory is social networks. This stock of social capital leads to self reinforcing and cumulative (Putnam, 1993). For this reason, the content and scope of disaster management requires integration and good synergy between the role of government and social capital, from prevention management to reconstruction management.

But unfortunately, there are still many problems faced in achieving integrated disaster management including weak coordination, limited human resources, facilities and infrastructure and supporting equipment. The strategy applied in various disaster management programs should use the basic principle that disaster victims are not passive who only mourn their fate and wait for help.

Since 2011, the Provincial Government of Bali has implemented disaster management programs and activities with the community in developing themselves and their environment independently and participatively at every stage of disaster management from pre-disaster, 
during emergency response and post-disaster in Bali Province. This followed up on the results of the Bali Bappeda and PPLH studies at Udayana University (2006) which showed that Bali Province had the potential and vulnerability to various natural and social disasters with the support of incident data with 6,245 disasters or disasters in regencies or cities throughout Bali.

One of the catastrophic events that had a broad impact on social, economic and psychological conditions was market fires, especially in the Denpasar, Badung, Gianyar Tabanan (Sarbagita) region of Bali Province. Traders will lose their place and business capital and potentially cause new unemployment problems, while on the consumer side they have difficulty obtaining their needs. Surya Aryanto (2011) in the study of the analysis of factors affecting market traders income after the Kliwon Temanggung market fire found that trading hours, trading capital and trading places simultaneously had a positive and significant effect on market traders income. But due to fires, market traders income variations declined to 81.7 percent. For this reason, the local government is expected to help provide capital with low interest and a repayment period that is in accordance with the ability of traders.

In addition to assistance from the government, disaster management activities are also carried out by the community and the business community in the form of fundraising, social services and so on. The participation of the community and the business community on disaster management aims to be able to reduce the risk of disasters that occur. However, it should be noted that the assistance of the community and the private sector is not only limited to providing assistance to disaster victims, but this assistance can lead to disaster risk reduction or prevention activities.

In terms of recovering victims of disasters, especially market fires in the Sarbagita area of Bali Province, it is still considered unable to show optimal performance. This is due to the fact that the recovery of victims of disasters is still running partially and is oriented towards disaster response. Along with the change in the management paradigm of the response from the original oriented during the emergency response to the stage of preparedness, it is deemed necessary to know the role of government and community social capital in disaster management towards the economic recovery of disaster victims in the Sarbagita region of Bali Province.

\section{LITERATURE REVIEW}

The government is the outoritative direction and administration of the affairs of men or women in a nation state, city, etc (Riawan, 2005). While Kaufman (in Thoha, 1995) states that the function of government is to serve and regulate society. If it is associated with disaster management, the indicator of the role of local government can refer to indicators of the role of the government in developing SMEs, namely as facilitators, regulators and catalysts (Diva, 2009).

Coleman (1999) states that social capital is an obligation and expectation, channels of information and social norms. Whereas Ridell (1997) in Suharto (2007), states that there are three main elements of social capital, such as trust, norms and networks.

Law No. 24 of 2007 states the importance of three pillars of Disaster Management actors, namely the government, the community, and business institutions to unite in carrying out disaster management. Broadly speaking, disaster management activities are classified into 6 (six) activities, such as mitigation, preparedness, early warning, emergency response, rehabilitation and reconstruction.

Recovery of post-disaster areas needs to be adjusted to the Regulation of the Head of the National Disaster Management Agency (BNPB) No. 11 of 2008 concerning the Guidelines for Post-Disaster Rehabilitation and Reconstruction. In the scope of the implementation of rehabilitation and reconstruction, post-disaster recovery includes social, economic and cultural recovery aimed at returning social, economic and cultural activities and communities in the affected areas such as before the disaster. 




Figure 1 - Research Framework

The research conceptual framework influences the role of government and social capital in disaster management for economic recovery as follows:

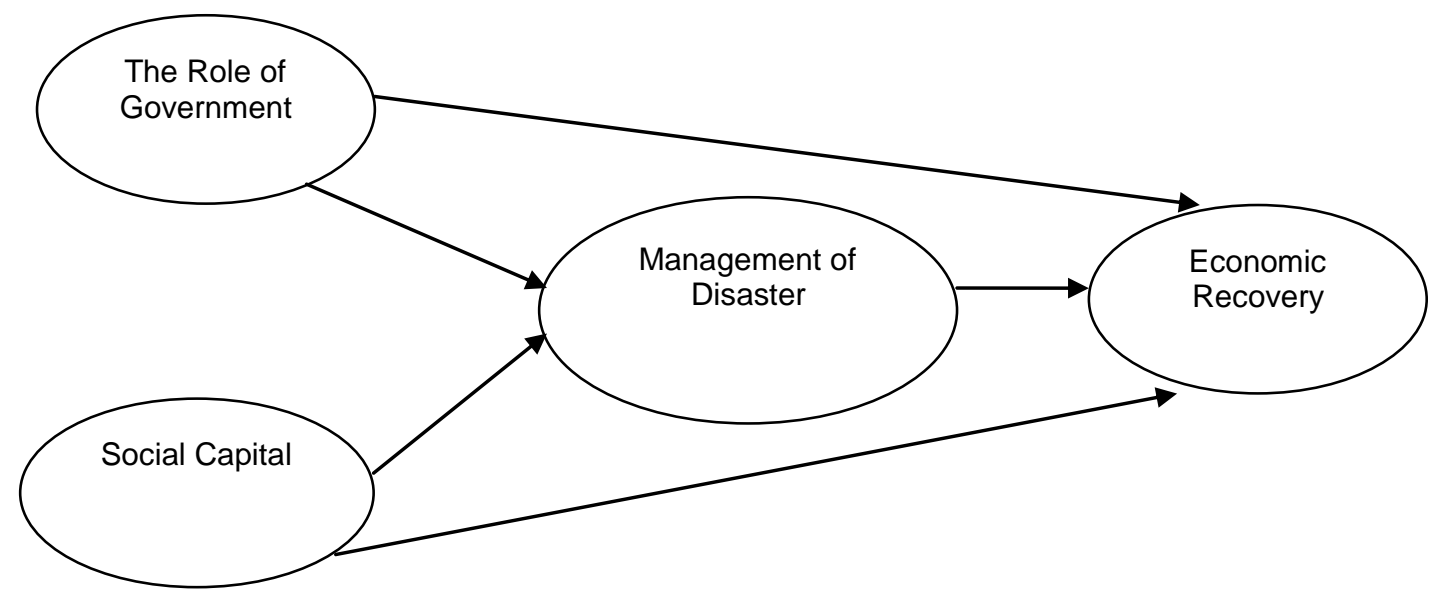

Figure 2 - Research Conceptual Framework

Based on the subject matter, research objectives, literature review and research conceptual framework, the hypothesis proposed in this study is as follows:

- The role of the government has a positive effect on disaster management;

- Social capital has a positive effect on disaster management;

- The role of the government has a positive effect on the economic recovery of postdisaster victims;

- Social capital has a positive effect on the economic recovery of post-disaster victims;

- Disaster management has a positive effect on the economic recovery of post-disaster victims;

- The role of the government indirectly affects the economic recovery of post-disaster victims through disaster management;

- Social capital has an indirect effect on the economic recovery of post-disaster victims through disaster management. 


\section{METHODS OF RESEARCH}

The method used in this analysis was a quantitative method. The technique used in the data instrument test included validity and reliability. This study used Partial Least Square (PLS) which consists of a measurement model or an external model and a structural model or internal model.

In this study, the research subjects were traders who were victims of market fires in the Sarbagita region of Bali Province. The number of samples based on Slovin formula as many as 96 people was chosen strata, random and proportional. In addition, several opinions of government and community leaders were also needed to represent and can provide positive input for post-disaster economic recovery.

In this study, the independent variable wass the role of government (X1) and social capital (X2), the variable between is disaster management $(\mathrm{Y} 1)$, while the independent variable is economic recovery (Y2).

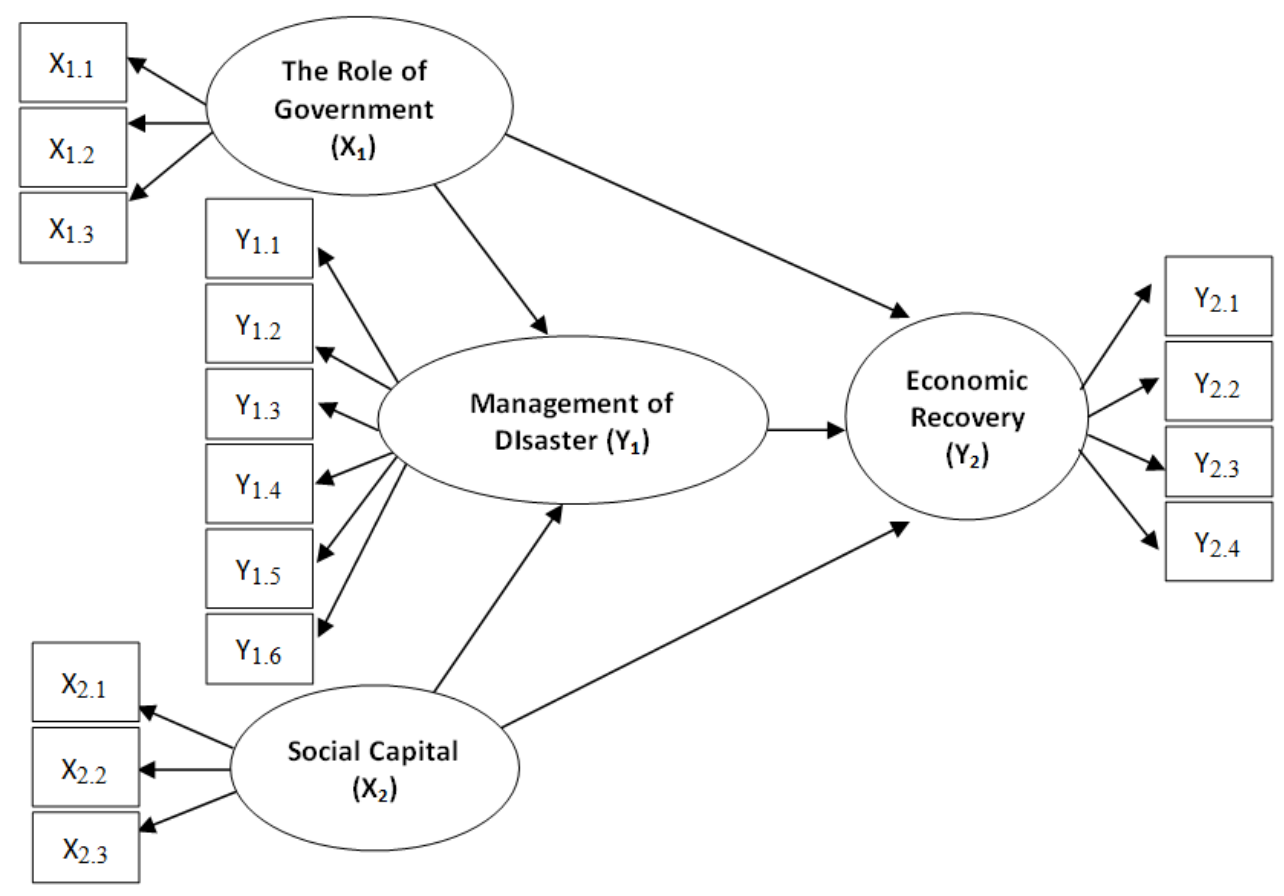

Figure 3 - Relationship between Research Variables

\section{RESULTS AND DISCUSSION}

The total determination coefficient of the structural equation from this research model shows that 61.6 percent of the economic recovery variables can be explained by the research model, while the excluded data is explained by other variables outside the research model.

The results of hypothesis testing show that the role of the government has a positive and significant effect on disaster management with a regression coefficient of 0.412 . Social capital has a positive and significant effect on disaster management with a regression coefficient of 0.505 . Disaster management has a positive and significant effect on economic recovery with a regression coefficient of 0.491 . While the role of government has a positive but not significant effect on economic recovery with a regression coefficient of 0.190 ; and the direct effect of Social Capital has a positive but not significant effect on Economic Recovery with a regression coefficient of 0.163 .

The role of government (X1) has a significant influence on economic recovery (Y2) through disaster management $(\mathrm{Y} 1)$ with a path coefficient of 0.202 . Whereas social capital 
(X2) has a significant influence on economic recovery (Y2) through disaster management (Y1) with a path coefficient of 0.248 .

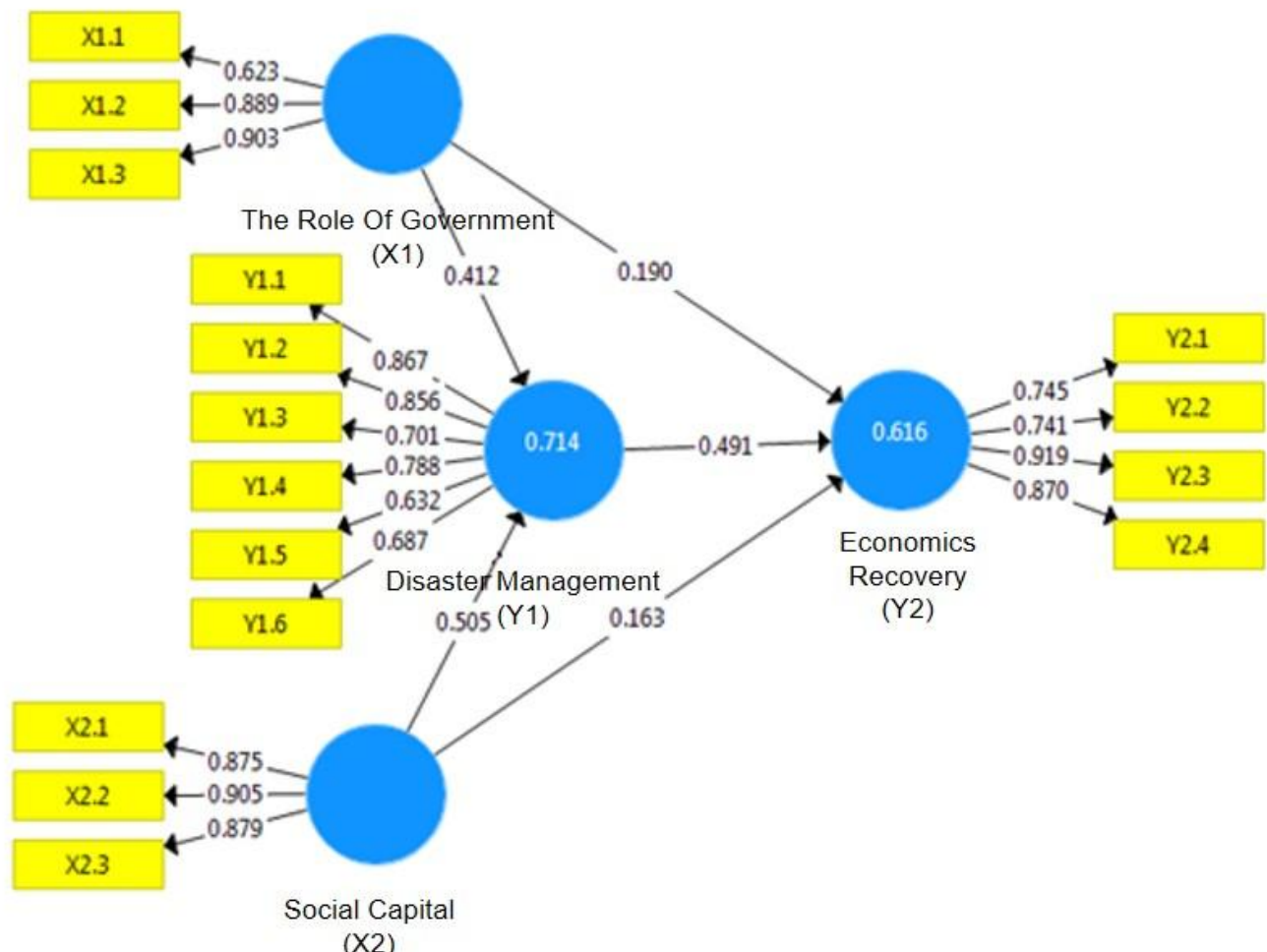

Figure 4 - Full Model of Determinants of Disaster Victims Economic Recovery in the Sarbagita Region of Bali Province

Table 1 - Direct Effect

\begin{tabular}{|c|l|c|c|c|c|}
\hline No & \multicolumn{1}{|c|}{ Direct Effect } & $\begin{array}{c}\text { Original } \\
\text { Sample }\end{array}$ & $\begin{array}{c}\text { Standar } \\
\text { Deviation }\end{array}$ & $\begin{array}{c}\text { T } \\
\text { Statistic }\end{array}$ & Information \\
\hline 1 & $\begin{array}{l}\text { The Role of Goverment } \rightarrow \text { Management of } \\
\text { Disasters }\end{array}$ & 0,412 & 0,082 & 5,014 & Significant \\
\hline 2 & $\begin{array}{l}\text { Social Capital } \rightarrow \text { Management of } \\
\text { Disasters }\end{array}$ & 0,505 & 0,095 & 5,334 & Significant \\
\hline 3 & $\begin{array}{l}\text { The Role of Goverment } \rightarrow \text { Economic } \\
\text { Recovery }\end{array}$ & 0,190 & 0,147 & 1,295 & $\begin{array}{c}\text { Not } \\
\text { Significant }\end{array}$ \\
\hline 4 & Social Capital $\rightarrow$ Economic Recovery & 0,163 & 0,130 & 1,252 & $\begin{array}{c}\text { Not } \\
\text { Significant }\end{array}$ \\
\hline 5 & $\begin{array}{l}\text { Management of Disasters } \rightarrow \text { Economic } \\
\text { Recovery }\end{array}$ & 0,491 & 0,130 & 3,770 & Significant \\
\hline
\end{tabular}

Source: Results of Study.

Table 2 - Indirect Influence Test Results

\begin{tabular}{|c|c|c|c|c|}
\hline \multirow{2}{*}{ No } & \multicolumn{2}{|c|}{ Testing } & \multirow{2}{*}{ Indirect Effect } & \multirow{2}{*}{ Conclussion } \\
\hline & Direct Effect & Indirect Effect & & \\
\hline 1 & $\begin{array}{c}\mathrm{X} 1 \rightarrow \mathrm{Y} 1 \\
\text { Coefficient }=0,412 \\
\quad(\text { significant })\end{array}$ & $\begin{array}{c}\mathrm{Y} 1 \rightarrow \mathrm{Y} 2 \\
\text { Coefficient }=0,491 \\
\text { (significant) }\end{array}$ & $\begin{array}{c}\mathrm{X} 1 \rightarrow \mathrm{Y} 2 \\
\text { with mediation } \\
\mathrm{Y} 1 \\
0,412 \times 0,491= \\
0,202\end{array}$ & $\begin{array}{l}\text { The indirect effect of } \mathrm{X} 1 \text { on } \mathrm{Y} 2 \text { with } \\
\text { mediation } \mathrm{Y} 1 \text { is significant }\end{array}$ \\
\hline 2 & $\begin{array}{c}\mathrm{X} 2 \rightarrow \mathrm{Y} 1 \\
\text { Coefficient }=0,505 \\
\quad(\text { significant })\end{array}$ & $\begin{array}{c}\mathrm{Y} 1 \rightarrow \mathrm{Y} 2 \\
\text { Coefficient }=0,491 \\
\text { (significant) }\end{array}$ & $\begin{array}{c}\mathrm{X} 2 \rightarrow \mathrm{Y} 2 \\
\text { with mediation } \\
\mathrm{Y} 1 \\
0,505 \times 0,491= \\
0,248\end{array}$ & $\begin{array}{l}\text { The indirect effect of } \mathrm{X} 2 \text { on } \mathrm{Y} 2 \text { with } \\
\text { mediation } \mathrm{Y} 1 \text { is significant }\end{array}$ \\
\hline
\end{tabular}

Source: Results of study. 


\section{DISCUSSION OF RESULTS}

The results of the analysis in this study state that the role of the government has a positive and significant effect on disaster management. In line with the research conducted by Abdul Latief (2015) which highlighted the role of local governments in disaster management, the government has the responsibility and authority to integrate disaster management on development to protect the public from disaster threats by implementing efforts in various aspects including planning, institutions, funding and capacity building. Planned disaster management in development, both in the medium and long term, compiling contingency plans, emergency operations, recovery and integrating it with the Regional Spatial Plan. The establishment of National Board for Disaster Management and Regional Board for Disaster Management is intended to formulate and establish disaster management policies and handling disaster victims by acting quickly and accurately, effectively and efficiently, and coordinating the implementation of planned, integrated and comprehensive disaster management activities. In terms of funding, the government is obliged to allocate and account for the use of the budget for disaster management such as routine and operational funds, contingency funds and ready to use for emergency response, as well as rehabilitation and reconstruction recovery funds. In addition, the government can mobilize and oversee the collection of funds from the community and use and account for national \& international donations or assistance. Capacity development includes the development of human resources in the form of formal, informal and non-formal education, managerial and technical training, drill practice, simulation and rehearsal, institutional development in the form of operations centers, data centers and media centers and infrastructure development in the form of information and communication technology improving the quality of services for disaster management programs.

The Director of Denpasar Regional Market Company IB Kompyang Wiranata stated that as one of the fire disaster relief efforts, the rebuilding of Badung Market had been started since 2017 and is expected to be completed by the end of 2018. With the completion of development, the market can already be used and traders can move from temporary selling location at Tiara Grosir to their new kiosk at Badung Market. The concept of revitalizing Badung Market is a public market with modern services equipped with elevators and escalators to facilitate movement and public facilities such as breastfeeding. In addition, Badung Market will apply certain standards to minimize fires. The Badung Market has a water reservoir located above the building to extinguish the fire in the event of a fire and place hydrants and smoke detectors in several places.

Disaster Management is a process cycle or flow of disaster risk reduction activities, starting from the planning, dissemination, implementation and supervision stages both at the time before they occur, when they occur and after the occurrence of a disaster. In order for disasters to be managed properly and safely, good disaster management is needed by the government. Planning, identifying resources, warning systems, training, simulations and actions taken by the government must achieve the main objectives of increasing the security and effectiveness of community responses during disasters. This is based on the consideration that the community can play a role not only as a disaster object but also as the subject of the disaster.

The results of the analysis in this study state that social capital has a positive and significant effect on disaster management. Social capital is the norm, institution and social relationship that form the quality of social interaction in society that allows people to work together. With the existence of trust, norms and networks in society, social capital is an important factor in disaster management. Social capital is needed by the community, especially in disaster-prone areas to anticipate the threat of disasters by utilizing the resources in their area.

The success of disaster management efforts depends on the active role of the community. Communities can take part in disaster management such as caring and disaster preparedness groups, increasing capacity in terms of disaster knowledge through education, training, skills and simulation or rehearsal, as well as carrying out disaster management 
efforts. Social capital can be categorized into two levels, thay are micro level in the form of networks that allow one to get help to reduce the suffering caused by the disaster, and at the macro level in the form of social organizations driven by citizens, supported by norms and mutual trust, to jointly and coordinated encourage the mitigation of the impact of disasters and the restoration of socio-economic conditions such as before the disaster occurred (Hawkins and Maurer, 2009). As stated by Ni Nyoman Witariani, a vegetable trader at the Badung market:

"We were confused by the market fire incident at that time, what about the fate of our merchandise, capital was burned out, but we believe the public and the government will immediately provide the best solution even though it may not be as expected".

The application of social capital in the event of market fires in the Sarbagita region of Bali Province includes the trust of the victims that the government and the community will carry out efforts to accelerate their economic recovery even though there are some obstacles faced at the beginning of the post-fire such as loss of customers, narrow parking a narrow relocation place and far from the previous Badung Market. Good social capital will support the success of the community in dealing with natural disasters. This is in line with the research conducted by Silmi Annisa Fahma (2016).

The results of the analysis in this study state that the role of the government has a positive but not significant effect on the level of economic recovery of disaster victims in the Sarbagita region of Bali Province. Although not significant, the government has a role in efforts to develop a community economic recovery program in the form of assistance shortly after a disaster or an economic recovery program to restore disaster victims to normal life as before. As stated by A.A. Ketut Kartika, SH, Head of the Badung Market Unit:

"There are some things that can be done to ease the burden of traders based on the direction of the Minister of Cooperatives, including calling on the implementing banks of the People's Business Credit (KUR) to restructure the debt of traders of fire victims, and temporarily relocating market traders while waiting for market repairs to be completed".

Rebuilding infrastructure, providing stimulus funds, restoring social psychological conditions and public services play an important role in the process of reviving the postdisaster regional economy. With the existence of physical development, it will automatically open up employment opportunities which will indirectly rotate the economy which can increase people's purchasing power. However, the role of the Government should not bring the community into a trap of dependence (charity), the role of the Government must instead deliver to the recovery process of disaster victims independently.

The phasing of the reconstruction program is needed and in each stage a program that is right on target is designed and designed in such a way that in addition to restoring the situation (infrastructure, social and economic life, institutions, etc.), it is also intended to reduce the risk of loss and catastrophic events in the future. After the restoration is completed, the foundation for sustainable growth needs to be laid. Reconstruction should be an effort to reduce disaster risk in the future (ex-ante risk reduction), not merely an effort to restore the condition of an ex-post disaster (Nazamuddin, 2007). It is in line with the research conducted by Rizka Rahma Maulida (2015) which stated that the economic impact in NAD due to the tsunami disaster caused significant inflation of $7.02 \%$. To overcome the economic impact, the basic principles and medium to long-term policy directions are drawn up.

The results of the analysis in this study state that social capital has a positive but not significant effect on the level of economic recovery of disaster victims in the Sarbagita region of Bali Province. Although not significant, social capital is a mechanism and the relationship between trust, norms and networks in social settings in an area (Woolcock, 1998). These values can be used as strong capital that is built in the community and local organizations in the protection of disaster-prone areas. For this reason, it is necessary to carry out an inventory of each type of local wisdom as a source and form of social capital. This is inseparable from the assumption that there is no society at all without having power. Every community must have power, but sometimes they are not aware or that power is still not explicitly known. Local potential must be explored and then developed where one of them is tolerance and mutual cooperation. If this assumption develops, social capital can be used as 
a means to build power, by encouraging, motivating and raising awareness of the potential that is owned and trying to develop it. This is in line as stated by Dayu Kirana, a cloth trader at the Ubud market:

"At that time all of my merchandise burned out, but fortunately there was a kind friend to lend his merchandise, if the profit was divided in two, so first the way I survived selling".

One of the determinants of the success of a development program is the potential of the community (Irawaty Igirisa). Population potential is the whole aspect associated with the condition or potential possessed by the population which includes the population, education level and comparison of the age of the population that can be used to develop the capacity of the population as program targets. Social capital is carried out to enlarge the potential of the community to develop their abilities which ultimately determines the success of a development program.

The results of the analysis in this study state that disaster management has a positive and significant effect on the economic recovery of disaster victims in the Sarbagita region of Bali Province. In the disaster, there are two key words, they are danger and vulnerability. Danger is an extraordinary natural phenomenon that has the potential to damage or threaten human life, loss of property, loss of livelihood, environmental damage. Whereas vulnerability to disaster impacts or risks is the condition or biological, geographical, social, economic, political, cultural and technological characteristics of a community in a region for a certain period of time which reduces the ability of the community to prevent, reduce, achieve readiness, and respond to the effects of certain hazards (Nurjanah, 2012). Thus the occurrence of disasters basically depends on the level of vulnerability of individuals, groups, environments, and institutions within a community.

In an effort to reduce the impact of disasters a disaster management management is needed that aims to increase the capacity and potential that exists in each individual and social group. This capacity can be related to resources, skills, knowledge, organizational capabilities and attitudes to act and respond to a crisis. Disaster management is a series or cycle of activities starting from the establishment of development policies based on disaster risk and followed by stages of disaster prevention activities, emergency response and rehabilitation. As stated by I Komang Kusumaedi, Head of the Emergency and Logistics Division of the Bali Province Disaster Management Agency:

"Programs with preventive, mitigation, preparedness content to the early warning that is available in each of these regional organizations must be able to connect, collaborate and together we choose to be implemented in Bali. Because BPBD cannot and is impossible to work alone in making disaster risk reduction programs without the support, participation, assistance and collaboration of other regional device organizations".

Disaster risk reduction proclaimed by policy makers must be able to reduce the threat of disaster hazards, increase capacity and reduce vulnerability, and pay attention to the links between disasters and development. Everyone needs to be introduced to various disaster hazards in their area, ways to avoid and reduce the hazards and vulnerabilities they have, and improve their ability to deal with disasters. In its implementation it is necessary to follow and pay attention to local wisdom and traditional knowledge in the community.

Recovery is the beginning of rebuild and become a part of the development that is generally carried out. The aim is to develop social, economic and cultural activities with the main goal of functioning as a return to social and cultural economic activities, the establishment of law and order and the rise of community participation in all aspects of life. The recovery aspect is related to the improvement and restoration of all aspects of public or community services to an adequate or normal level, including socio-economic recovery for the medium and long term.

Disaster management policies prepared by the government for economic recovery of disaster victims will be more beneficial if the community is involved both directly and indirectly in all efforts to reduce disaster risk. This is because the public knows more about potential hazards, threats, vulnerabilities and capacities that are in accordance with their territory. The implementation of effective and efficient disaster management needs to be supported by all pillars, such as the government, business institutions and the community. In 
addition, it is necessary to implement a national movement to arouse awareness, increase awareness and preparedness of all stakeholders, including government, society and business institutions as an effort to change the paradigm of disaster management from disaster emergency response to reducing and managing disaster risk. As stated by Ida Bagus Yama, Head of the Prevention and Preparedness Division of the Bali Province Disaster Management Agency:

"Disaster education must be started early, especially in disaster-prone areas, to schools through teachers and the community, and to carry out regular and continuous disaster management simulations".

Through practice and simulation it is hoped that the community can recognize disaster threats and be vigilant in disaster emergency situations. Desti Nisa Isti's research (2017) shows that almost all government programs and projects require community participation and empowerment that determine the success of development programs.

In an effort to succeed the economic recovery of disaster victims, Social Capital is very much needed in efforts to mitigate the impact of disasters, besides physical capital, financial capital, human capital (Hawkins and Maurer, 2009). Communities and business institutions can initiate activities that are able to alleviate the suffering of fellow citizens who are affected by disasters, at least in the short term, such as providing substantial labor and material assistance. However, the government's role in medium and long term recovery remains irreplaceable. As stated by I Nyoman Gunawan, fruit traders in the Badung market:

"Indeed the community helped by collecting donations, the government also relocated us temporarily in order to remain able to sell but the size was very narrow. Indeed, for a while, but the calculation is not monthly, but it can be annual because the rebuilding of the market is quite long, making us also lose customers, if we like this we continue to lose money".

Disaster management policies and programs carried out by the government must pay attention to the socio-economic conditions of victims of diverse disasters and local cultures. Communities with weaker socio-economic status tend to have more limited social capital than socioeconomic stronger communities. The recovery efforts carried out by the government, the community and business institutions must be more intensive and comprehensive for victims of disasters with weak socio-economic conditions considering that financial capital, resource capital (knowledge and skills) and social capital (social networks) are generally weaker. This is in line with the results of research conducted by R.A Tachya Muhamad, et al (2017).

\section{CONCLUSION AND RECOMMENDATIONS}

The role of government and social capital has a positive and significant effect on disaster management in the economic recovery of disaster victims in the Sarbagita region of Bali Province. If the role of government and social capital increases, disaster management will also improve.

The role of government and social capital has a positive effect with low significance on the economic recovery of disaster victims in the Sarbagita region of Bali Province. If the role of government and social capital increases, the economic recovery will also increase but not significantly. Whereas disaster management has a positive and significant effect on the economic recovery of disaster victims in the Sarbagita region of Bali Province, which means that the better the disaster management, the economic recovery will also increase.

The role of government and social capital has an indirect significant effect on the economic recovery of disaster victims in the Sarbagita region of Bali Province through disaster management. If the role of the government and disaster management gets better, the economic recovery will also improve. Likewise, the better social capital and disaster management, the better economic recovery will be.

Based on the results of the study, several suggestions can be made to accelerate the economic recovery of disaster victims in the Sarbagita region of Bali Province as follows: 
The government as the regulator must take a stand in improving disaster management programs towards a better one by conducting policy socialization and thorough evaluation both in terms of facilities, infrastructure and quality of human resources. The prepared disaster management program is strived to be sustainable and directed in the short, medium and long term.

Efforts should be made to increase mutual trust between the community and the government, especially in terms of disaster management and economic recovery activities such as reducing rapid response time, providing disaster relief, capital assistance and implementing educational programs for disaster risk reduction.

Disaster management programs must continue to be improved to improve the economic recovery of disaster victims. One of them is by providing an integrated early warning system that can provide information quickly and precisely by utilizing all communication information technology media. Of course the infrastructure that has been built must be supported by an adequate maintenance budget so that the system can function optimally.

Economic recovery can be accelerated by providing physical infrastructure that meets safety standards and protection against disasters. Collaboration with financial institutions or banks related to delays in payment of bank loans by traders, extension of credit repayments, soft loan distribution for strengthening and development of capital are also expected to be able to assist the economic recovery process for medium and long-term rehabilitation and reconstruction. In addition, the economic recovery of disaster victims can be improved by considering other external factors, namely the participation of the business or the private sector, the superior potential of the population and the natural resources of the disaster location, the development of science and technology, and social, economic, political and cultural institutions local.

\section{REFERENCES}

1. Abdul Latief. 2015. Peran Pemerintah Daerah dalam Penanggulangan Bencana Alam di Kota Palopo, Skripsi, Universitas Hasanuddin, Makassar.

2. Adger, N. 2003. Social Capital, Collective Action, and Adaptation to Climate Change. Economic Geography, Vol. 79, No. 4, 387-404.

3. Affeltrnger, B, Alcedo, Amman,W.J, Arnold, M. 2006. Living with Risk, "A Global Review of Disaster Reduction Initiatives". Buku terjemahan oleh MPBI (Masyarakat Penanggulangan Bencana Indonesia), Jakarta.

4. Ahmad Ubaidillah. 2018. Pemulihan Ekonomi Pasca Bencana Banjir melalui Usaha Kerajinan Tas Limbah Plastik Bagi Petani Di Dusun Koryo Desa Bulutigo Kecamatan Laren Kabupaten Lamongan. Skripsi, Universitas Islam Negeri Sunan Ampel, Surabaya

5. Arsyad, Lincolin. 2010. Ekonomi Pembangunan. Yogyakarta: Penerbit UPP STIM YKPN.

6. Ashley, C. 2003. Dynamics of Livelihood Change. Understanding Livelihoods in Rural India: Diversity, Change and Exclusion.

7. AusAid. 2005. Economic Impact of Natural Disaster on Development in The Pacific. Vol.2 Economic Assesment Tool.

8. Baiquni. 2006. Strategi Penghidupan Di Masa Krisis. Ideas Media Yogyakarta Tahun 2007.

9. Bappeda Bali and PPLH UNUD. 2006. Studi Identifikasi Potensi Bencana Alam Di Provinsi Bali, Laporan Penelitian, Badan Perencanaan Pembangunan Daerah Provinsi Bali and Pusat Penelitian Lingkungan Hidup Lembaga Penelitian Universitas Udayana, Denpasar.

10. Badan Penanggulangan Bencana Daerah Provinsi Bali. 2014. Laporan Bencana Bulanan Provinsi Bali. Badan Penanggulangan Bencana Daerah Provinsi Bali.

11. Badan Nasional Penanggulangan Bencana. 2008. Peraturan Kepala Badan Nasional Penanggulangan Bencana (BNPB) No 11 Tahun 2008 tentang Pedoman Rehabilitasi and Rekonstruksi Pasca Bencana. Badan Nasional Penanggulangan Bencana. 
12. Bayudono, T. I. 2009. Disaster management post earthquake in Yogyakarta, Indonesia. Science without borders, 3, 338-348.

13. Buckle, P, Marsh, G. and Smale, S. 2001. Assessment of personal and community resilience and vulnerability. Emergency Management Australia Report 15/2000.

14. Bureau for Crisis Prevention and Recovery-Disaster Reduction Unit of United Nations Development Programme. 1992. Post-Disaster Recovery Guidelines.

15. Coleman, J.1999. Social Capital in the Creation of Human Capital. Cambridge Mass: Harvard University Press.

16. Coleman, J. 1990, Foundations of Social Theory. Cambridge: Harvard University Press.

17. Coppola, D.P. 2007. Introduction to International Disaster Management. Oxford: Butterworth-Heinemann.

18. Darmajanti Linda. 2002. Kehidupan Berorganisasi Sebagai Modal sosial Komunitas Jakarta. Disertasi, Program Pascasarjana Ul. Jakarta.

19. Depkominfo RI. 2007. Penanggulangan Bencana Alam dalam Perspektif Agama di Indonesia. Depkominfo RI, Jakarta.

20. Desti Nisa Isti. 2017. Persepsi and Partisipasi Masyarakat Terhadap Pemanfaatan Dana Desa Untuk Pemberdayaan Masyarakat Di Desa Kertajaya Kecamatan Padalarang Kabupaten Bandung Barat. Jurnal Pendidikan Luar Sekolah Volume I, nomor 1, April 2017.

21. Dhini Rama Dhania. 2012. Copying Stress Pedagang Pasar Kliwon Kabupaten Kudus Pasca Kebakaran. [Online] Jurnal Sosial Budaya Tersedia di http://jurnal.umk.ac.id/index.php/sosbud/article/view/393/484 [diunduh: 22 Mei 2017].

22. Effendi s, M. Singarimbun. 1982. Metode Penilaian Survey. LP3ES, Jakarta.

23. Fajri Muharja. 2014. Modal Sosial and Proses Pemulihan Pasca Bencana Tsunami Aceh. Jurnal online, http://www.academia.edu/ Diunduh 14 Oktober 2018

24. Fukuyama, F. 1999. Social Capital and Civil Society. Paper presented at the IMF Conference on Second Generation Reforms, November 8-9, 1999, IMF Institute and the Fiscal Affairs Department, Washington, D.C.

25. Fukuyama Francis. 1995. Trust: The Social Virtues and the Creation of Prosperity. London: Penguin Books.

26. Fukuyama Francis. 2001. Social capital, civil society and development. Third World Quarterly, 22(10:7-20).

27. Francois, P. 2003. Sosial Capital and Economic Development. London: Routledge.

28. Gambetta, D. 2000. Trust: Making and Breaking Cooperative Relations. Electronic Edition.Chapter 13. Oxford: Department Sociology, University of Oxford, 213-37.

29. Gozali, Imam. 2008. Structural Equation Modeling: Metode Alternatif dengan Partial Least Square (PLS). Badan Penerbit Undip, Edisi 2. Semarang,

30. Haifani. 2008. Manajemen Risiko Bencana (Studi Kasus Gempa Yogyakarta 27 Mei 2006). Jurnal Pusat pengkajian Sistem and Teknologi Keselamatan.

31. Haris, A.-M, \& Purnomo, E. P. 2016. Implementasi CRS (Corporate Social Responsibilty) PT. Agung Perdana Dalam Mengurangi Dampak Kerusakan Lingkungan (Study Kasus Desa Padang Loang, Seppang and Desa Bijawang Kec. Ujung LoeKab. Bulukumba). Jurnal Ilmu Pemerintahan \& Kebijakan Publik, 3, 203-225.

32. Hasbullah, J. 2006. Social Capital: Menuju Keunggulan Budaya Manusia Indonesia. Jakarta: MR-United Press.

33. Hewitt, K.1997. Regions at risk. Harlow:Longman

34. Igirisa, Irawaty. Faktor-Faktor Yang Menentukan Keberhasilan Dalam Kebijakan Pengembangan Usaha Tani Di Kabupaten Gorontalo. Fakultas Ekonomi and Bisnis Universitas Negeri Gorontalo.(Accessed 1 Maret 2017].

35. Jaya, I.G.N.M. \& Sumertajaya, I.M. 2008. Pemodelan Persamaan Struktural Dengan Partial Least Square. Prosiding Semnas Matematika and Pendidikan Matematika, 1, pp.118-32.

36. Jovel, J. Roberto. 2005. Assessment of the Socio-Economic Impact of Disasters: Conceptual Framework. ADPC. 
37. Hawkins and Maurer. 2009. Bonding, Bridging and Linking: How Social Capital Operated in New Orleans Following Hurricane Katrina. British Journal of Social Work.

38. Kusumasari, Bevaola. 2014. Manajemen Bencana and Kapabilitas Pemerintah Lokal. Yogyakarta: Gava Media

39. Listya Endang Artiani. 2011. Dampak Ekonomi Makro Bencana: Interaksi Bencana dengan Pembangunan Ekonomi Nasional. Seminar Nasional Informatika ( semnasIF, 2011), UPN Veteran Yogyakarta.

40. Liu, J, Qu, H, Huang, D, Chen, G, Yue, X,Zhao, X, Liang, Z. 2014. The Role of Sosial Capital in encouraging Residents' pro-environmental Behaviours in Community Based Ecotourism. Tourism Management 41, 190-201.

41. Mawardi, M.J. 2007. Peranan Social Capital Dalam Pemberdayaan Masyarakat. Jurnal Pengembangan Masyarakat Islam. Vol. 67. No.9.

42. Meier, G. M, \& Stiglitz, J. E. 2001. Frontiers of Development Economics: The Future in Perspective. World Bank Publications.

43. Muhamad, Tachya, Bintarsih Sekarningrumet and Yusar. 2017. Modal Sosial Dalam Penanggulangan Bencana Banjir (Kasus di Kabupaten Bandung, Jawa Barat). Sosioglobal: Jurnal Pemikiran and Penelitian Sosiologi. Universitas PadjajaranSemarang

44. Nazamuddin. 2007. Kebijakan Ekonomi untuk Mitigasi Bencana and Pemulihan PascaBencana: Pelajaran dari Bencana Tsunami di Aceh. Jurnal online, www.rp2u.unsyiah.ac.id/index.php/welcome/prosesDownload/247/1

45. Nurjanna, Dkk, 2012, Manajemen Bencana, Alfabeta, Bandung.

46. Nuryana, Mu'man. 2004. Modal Sosial dalam Isu-isu Tematik Pembangunan Sosial: Konsepsi and Strategi (Suharto, ed). Jakarta: Balitbangsos Depsos RI

47. Okuyama, Yasuhide. 2003. Economics of Natural Disasters: A Critical Review, Research Paper, presented at the 50th North American Meeting, Regional Science Association International, November 20-22, 2003, Philadelphia, PA.

48. Pelling, M. 2002. Assessing urban vulnerability and social adaptation to risk: evidence from Santo Domingo. International Development Planning Review 24(1),59-76.

49. Peraturan Presiden Republik Indonesia Nomor 30 Tahun 2005 tentang Rencana Induk Rehabilitasi and Rekonstruksi Wilayah and Kehidupan Masyarakat Provinsi Nanggroe Aceh Darussalam and Kepulauan Nias Provinsi Sumatera Utara

50. Peraturan Gubernur Bali Nomor 28 Tahun 2017 Tentang Perubahan Atas Pergub Nomor 60 Tahun 2015 tentang Santunan and Bantuan Sosial Perbaikan Sarana and Prasarana Perekonomian, Rumah Masyarakat and Fasilitas Umum untuk Korban Bencana

51. Pinkowski, Jack, 2008. Disaster Management Handbook. New York: Taylor \& Francis Group: CRC Press.

52. Pretty, J, Ward, H. 2001. Sosial Capital and The Environment. World Development Vol. 29, No. 2.

53. Purnomo, Hadi, 2010. Manajemen Bencana Respons and Tindakan terhadap Bencana. MedPress.

54. Purnomo, E. P, Nurmandi, A, Sulaksono, T, Hidayati, M, Ramdani, R, \& Agustiyara. 2017. Ekologi Pemerintahan: Tata Kelola and Kelembaman Birokrasi Dalam Menangani Kebakaran Hutan, Pengelolaan Sawit, Serta Peranan Elit Lokal. Yogyakarta: LP3M UMY.

55. Putnam, R.D, Leonardi, R. and Nanetti, R.Y. 1993. Making Democracy Work. Princeton: Princeton University Press.

56. Putnam R. 1995. The Prosporous Community, Social Capital and Public Life. The American Prospect, 13-65-78.

57. Putnam, R.D. 1995. Bowling Alone: America's Declining Social Capital. Journal of Democracy. VI: 65-78.

58. Ramli, Soehatman, 2010. Pedoman Praktis Manajemen Bencana (Disaster Management). Jakarta: Dian Rakyat.

59. REDLAC. 2006. Methodology Rapid Assessment for Humanitarian Assistance. Stephenson. 
60. Rizka Rahma Maulida. 2015. Pemulihan Ekonomi Kota Pasca Bencana Critical Review "Teknik Pembangunan Ekonomi Aceh Pascatsunami - Wahyuddin". Jurnal online, http://www.academia.edu/

61. Rijanta, D.R. Hizbaron, M. Baiquni. 2018. Modal Sosial dalam Manajemen Bencana. Gadjah Mada University Press

62. R.S. 1994. Disaster Assessment (2nd edition). United Nations Development Programme.

63. Schneid, Thomas D. Collins, Larry. 2000. Disaster management and preparedness. Lewis Publisher.

64. Universitas Udayana. 2015. Buku Pedoman Penulisan Usulan Penelitian, Tesis and Disertasi. Denpasar, Program Pascasarjana Universitas Udayana.

65. Siswanto, Dr. H. B, M.Si. 2005. Pengantar Manajemen. Jakarta: PT. Bumi Aksara.

66. Sumarni, 2013. Intervensi Pemerintah Antara Kebutuhan and Penolakan di Bidang Ekonomi. Economica, Jurnal Program Studi Pendidikan Ekonomi Vol 1 No. 2, April 2013.

67. Sugiono. 2007. Metode Penelitian Kualitatif and Kuantitatif, R\&D. Alfabeta: Bandung.

68. Sukandarrumidi. 2010. Bencana Alam and Bencana Anthropogene. Jakarta: Penerbit Kanisisus.

69. Supriyatna, Yayat. 2007. Analisis Dampak Bencana terhadap Perekonomian Indonesia dengan Pendekatan SNSE, Jurnal online, https://lib.ui.ac,id/file?file=digital/20285082T29478-Analisis\%20dampak.pdf

70. Syahyuti. 2008. Peran Modal Sosial (Social Capital) Dalam perdagangan Hasil Pertanian. (The Role Social Capital In Agricultural Trade). Forum Penelitian Agro Ekonomi Vol 26 No 1: 32-43. Bogor.

71. Tama, Novian Budi. 2012. Local Wisdom di Indonesia. Jurnal online, $\mathrm{http}: / /$ novian25.blogspot.com/2012/03-local-wisdom-di-indonesia.html.

72. Tearfund, 2006, Mainstreaming Disaster Risk Reduction. A Tool for Development Organisation, Tearfund, 100 Church Road, Teddington, Middlesex, TW11 8QE, UK.

73. Tolley's Handbook of Disaster and Emergency Management. Amsterdam: Elsevier.

74. Undang-undang Republik Indonesia Nomor 24 Tahun 2007 tentang Penanggulangan Bencana.

75. United Nations Development Programme. 1992. Tinjauan Umum Manajemen Bencana.

76. United Nations Disaster Relief Coordinator. 1991. Mitigating natural disaster phenomena, effects and options: a manual for policy makers and planners. New York: UN.

77. United Nations International Strategy for Disaster Reduction. 2004. Living with Risk "A Hundred Positive Examples of How People are making The World Safer" United Nation Publication, Geneva, Switzerland, 2004.

78. United Nations International Strategy for Disaster Reduction. 2005. Hyogo Framework for Action 2005-2015. United Nations International Strategy for Disaster Reduction.

79. Windia Wayan P, K.Sudantra, 2006. Pengantar Hukum Adat Bali, Lembaga Dokumentasi and Publikasi Fakultas Hukum Universitas Udayana, Denpasar.

80. Yuliarmi, Nyoman. 2011. Peran Pemerintah, Lembaga Adat and Modal Sosial Dalam Pemberdayaan Industri Kecil and Menengah (Studi Industri Kerajinan di Provinsi Bali. Disertasi, Tidak dipublikasikan, Universitas Brawijaya, Malang.

81. Yustika, Ahmad Erani. 2013. Ekonomi Kelembagaan (Paradigma, Teori and Kebijakan). Erlangga, Jakarta.

82. Vermeiren, J.C. 1991. Natural disasters: linking economics and the environment with a vengeance. In Girvan, N.P. and Simmons, D.A, editors, Caribbean ecology and economics. Barbados: Caribbean Conservation Association.

83. Vidia Reski Awalia, Mappamiring, \& Andi Nuraeni Ralsa. 2015. Peran Pemerintah Dalam Menanggulangi Resiko Bencana Banjir di Kabupaten Kolaka Utara, [Online] http://www.journal.unismuh.ac.id/index.php/Otoritas/article/download/124/11.

84. Zapata-Marti, R. 1997. Methodological approaches: the ECLAC methodology. In Center for the Research on the Epidemiology of Disasters (CRED), Assessment of the economic impact of natural and man -made disasters. Proceedings of the expert consultation on methodologies, Brussels, 29-30 September, Universite Catholique de Louvain, Belgium, 10-12. 